Article

\title{
Analysis of Rock Raw Materials Transport and its Implications for Regional Development and Planning. Case Study of Lower Silesia (Poland)
}

\author{
Jan Blachowski *(D) and Anna Buczyńska \\ Faculty of Geoengineering, Mining and Geology, Wrocław University of Science and Technology, \\ Wybrzeże Wyspiańskiego 27, 50-370 Wroclaw, Poland; anna.buczynska@pwr.edu.pl \\ * Correspondence: jan.blachowski@pwr.edu.pl; Tel.: +48-71-320-68-75
}

Received: 22 March 2020; Accepted: 13 April 2020; Published: 14 April 2020

check for updates

\begin{abstract}
The movement of rock raw materials from source to demand areas is carried out predominately with road and railway transport. The latter is less damaging to infrastructure, the environment and society and is cheaper for longer distances, but it is also less flexible and not widely used. The Lower Silesia region in southwestern Poland is an important producer of rock raw materials and the principal provider of igneous and metamorphic dimension stones and crushed rocks in the country. A multicriteria scoring scheme has been developed and applied to identify mines presently using road transport, that are predisposed to switch to or include a railway form of transport. Four criteria have been proposed, C1—distance to railway loading point, C2-annual production of rock raw material, C3-economic reserves, and C4-type of rock raw material. The scoring scheme (classification) was developed based on the results of descriptive statistics for mines presently using railway or combined road and railway forms of transport. Two scenarios were analyzed, one with equal weights $(0.25)$ and the other with higher significance of $C 1=0.40$ and $C 2=0.30$, and lower significance of $\mathrm{C} 3=0.20$ and $\mathrm{C} 4=0.10$. In the result, 24 mines were identified and ranked in terms of their potential to introduce railway transport. The proposed methodology can be used universally for other regions and countries, and the results will be included in drawing up regional spatial development policies.
\end{abstract}

Keywords: rock raw materials; transport; road; railway; multicriteria analysis

\section{Introduction}

Rock minerals such as dimension rocks and crushed stones (DSCR), as well as sands and gravels are raw materials that are considered to be key resources that enable proper functioning of the economy and satisfy the living standards of the society. Demand for these rock raw materials, which due to their properties are used in the construction industry including buildings, roads and railroads, is related to the economic growth. According to a study by the British Geological Survey, the production of DSCR between 2013 and 2017 increased by 8.6\% from 1,110,895.7 thousand Mg to 1,206,066.4 thousand Mg in European countries [1]. Poland, in 2017, was the seventh largest producer of dimension stones and crushed rocks, and the third largest of all aggregates.

Source areas of these rock raw materials (this term is used in our paper to cover all types of rock mineral raw materials) are conditioned by geology, and are usually unevenly distributed across a given area (e.g., region or a country). This is especially true for magmatic, metamorphic and sedimentary dimension stones and crushed rocks. Deposits of sands and gravels are more common and evenly distributed. In contrast, demand areas for these rock raw materials, urban areas and transport infrastructure construction sites, may be located at considerable distances, even hundreds of kilometers 
away from available sources. The need to move these materials from source to demand areas exerts pressure on existing transport networks, roads and railways, which are the typical means of transport for rock raw materials. Road transport, using tipper and semitrailer tipper trucks is usually used for shorter distances (tens of kilometers), whereas rail transport is used for longer distances (hundreds of kilometers). The factors determining the type of transport used include: the structure of supply and demand for rock raw materials, the availability of a given transport infrastructure, and the cost of transport (usually given per $\mathrm{km}$ ). Comparative analysis of costs for road and railway transport of rock raw materials was carried out by Gawlik et al. [2] and Kryzia and Kopacz [3]. Whereas, Nowakowski et al. [4] and Chęciński [5] focused on the problem of logistics of road transport and optimization of road transport routes. Beuthe et al. studied demand for different transport models (road, rail and inland water) for ten groups of commodities including mineral and building materials [6]. Łochańska and Stryszewski studied the demand and supply structure and concluded that in the case of rock raw materials, transport costs are higher that mining costs, with geological settings determining the locations of rock raw material quarry operations $[7,8]$. Blachowski analyzed the magnitude of rock raw material road transport sources in Lower Silesia (Poland) [9], and Kendal et al. assessed the energy and environmental costs of cement production in the USA with a comparison of large mining operations (megaquarries) and smaller scattered mines, and found out that transition to such megaquarries increases these costs by up to 50\% [10]. Elsewhere, Andrés and Padilla analyzed the energy intensity of transport for various types of commodities in Spain, including minerals and building materials [11]. A different aspect was analysed by Robinson and Kapo who investigated potential locations for recycled aggregates in relation to natural aggregate sites, transport network and population density [12]. Hill applied distance to road and railway networks as criteria to analyze and map rock aggregate opportunity areas over New Zealand [13]. Generally, railway transport of low value, high volume commodities such as rock raw materials is less conflictual than road transport. The latter is known for excessive levels of pollution and noise, damage to public roads, safety risks (accidents) and increased traffic. These factors generate conflicts with local communities.

The Lower Silesia region in Poland is the principal supplier of magmatic and metamorphic dimension stones and crushed rocks and is a major producer of sands and gravels that are transported to demand areas within the region as well as to other parts of the country. Thus, the two aims of this study are, first to statistically and spatially assess the scale of road and rail transport of rock raw materials in the Lower Silesia region of Poland, and secondly to propose and apply a method for the identification and selection of rock raw material quarrying operations predisposed to change to rail or combined road and rail forms of transport. The proposed method could be applied universally in other regions and countries.

\section{Description of Study Area}

Lower Silesia is one of the 16 voivodeships (highest level administrative units) of Poland, located in the southwest part of the country and bordering with the Czech Republic (in the South) and Germany (in the West). The region has an area of $19,946.7 \mathrm{sq}$. $\mathrm{km}$ with $29.6 \%$ of it covered by various forms of forest. Nature protection areas constitute $18.2 \%$ of the region's total surface, and when Nature 2000 sites are included this percentage rises to $35 \%$ [14]. The mining of nonferrous metals (copper and silver ore), energy minerals (brown coal) and numerous rock raw materials (many unique to the country) is an important part of the region's developing economy, which is one of the strongest in Poland.

\subsection{Geology and Mining of Rock Raw Materials}

The geological structure of Lower Silesia is mosaic and varied. This is the result of polyphasic geological evolution that lasted from the upper Proterozoic up to the Quaternary. The main geologic-tectonic structures run from the northwest to the southeast, and are the Fore-Sudetic Monocline (in the North of the region), the Fore-Sudetic Block and the Sudetes Mountains in the South, separated from the Block by the Sudetic Marginal Fault [15]. Some studies also suggest that the latter 
two are one structure, the Sudetic Block [16]. The extent of the three main geological units has been shown in Figure 1.

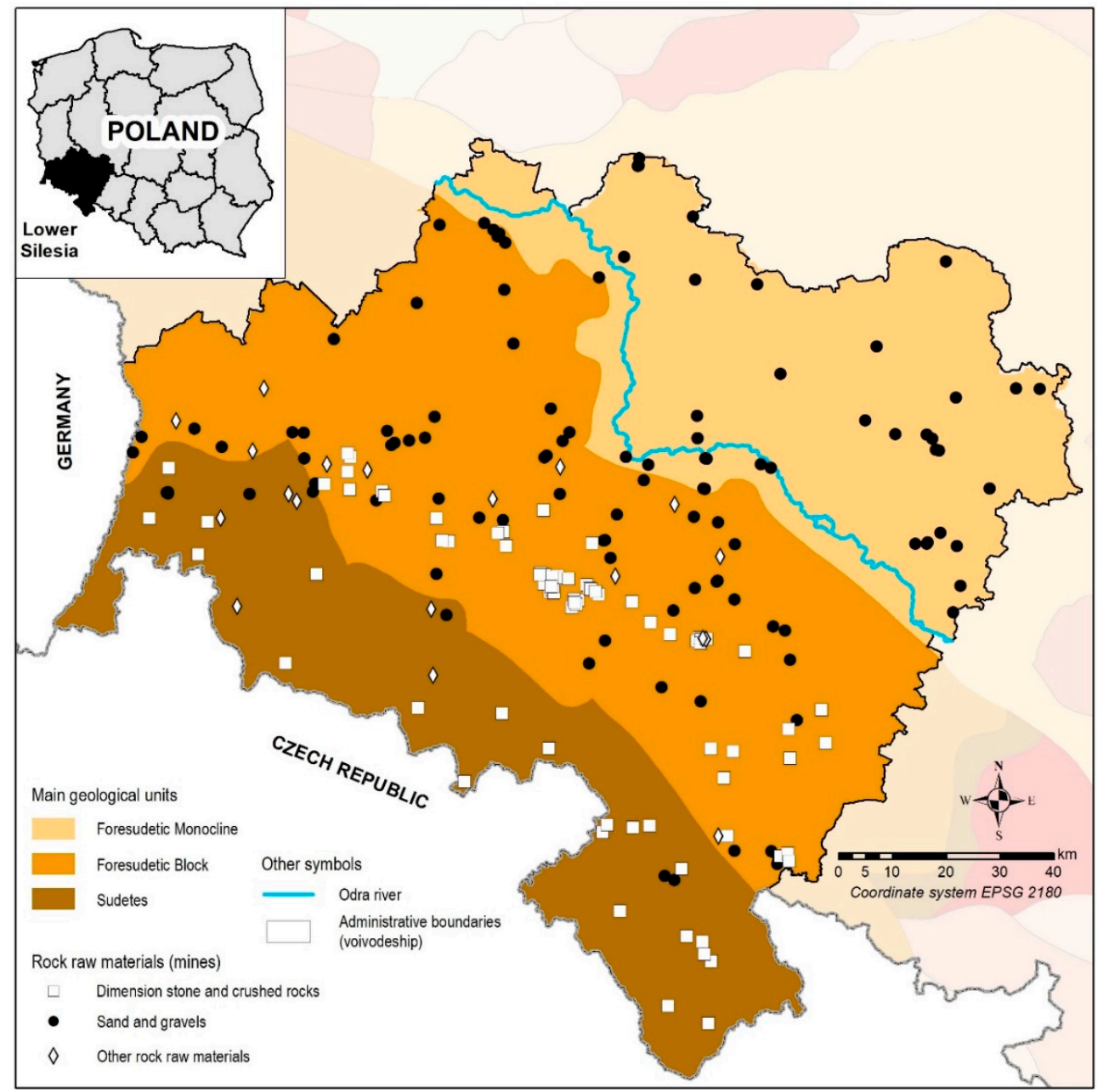

Figure 1. Location of active rock raw materials mines and general geological structure of the Lower Silesia Voivodeship.

The Sudetes Mountains are composed of various igneous, metamorphic and sedimentary rocks dating back to the Precambrian to the Cenozoic. These rocks build numerous smaller tectonic units separated by faults, and together form a mosaic geological surface. The Fore-Sudetic Block consists of two structural levels. The older one is built of metamorphic and igneous rocks. It is partly covered by deposits of sedimentary rocks making up the younger structural level. The unit is also characterized with mosaic composition, and numerous secondary elements have been identified there including gabbro, granite, and serpentinite massifs, metamorphic and other structures [15]. The Fore-Sudetic Monocline is composed of thick layers of Permian-Mesozoic origin lying inconsistently on a folded Paleozoic subsurface. The Permian-Mesozoic deposits generally lie at an angle of several degrees towards north and northeast. This geological context is the reason for the rich and diversified mineral resources documented in Lower Silesia. The dimension stones and crushed rocks deposits are predominately associated with rock massifs of the Sudetes and the Fore-Sudetic Block parts of the region. The sand and gravel deposits are more evenly distributed and associated predominately with Quaternary deposits, the most valuable of which are documented in fluvial formations of major river valleys and in glacial formations [17]. There are 258 documented deposits of all types of dimension stones and crushed rocks (132 with active mining permits), 477 documented deposits of sands and 
gravels, and numerous deposits of other industrial minerals, such as bentonite, feldspar, kaolin, white burning clays, glass sands. The region is the primary zone of dimension stones and crushed rocks of both igneous and metamorphic origin, with $77 \%$ of national economic reserves and $90.5 \%$ of annual production [18]. Lower Silesia has most of the national igneous rocks such basalt, granite, melaphyre, porphyry, as well as the only resources of gabbro and syenite in the country. The same can be said about metamorphic rocks, with the highest amount of the amphibolies, serpentine, hornfels, migmatite, marble [19]. Out of 231 deposits of igneous and metamorphic dimension stones and crushed rocks in Poland, 204 have been documented in Lower Silesia [18].

The Lower Silesia region provides approximately $45 \%$ of all DSCR in the country and between $85 \%$ to $100 \%$ of different types of igneous and metamorphic DSCR. Mining of sands and gravels provides between $7 \%$ and $8 \%$ of national consumption annually, whereas other rock raw materials such as bentonite, white burning ceramic clays and refractory clays, schists, magnesites, kaolin and feldspar are mined only in Lower Silesia.

\subsection{Railway Infrastructure}

The length of the Polish railway network is $19,132 \mathrm{~km}$ and decreased by $26 \%$ between 1991 and 2016. This trend is similar to other European countries, such as France and Germany. However, in the same period, $4500 \mathrm{~km}$ of railways have been modernized through the construction of second tracks, and another $500 \mathrm{~km}$ have been electrified [20]. The average density of railway network in Poland is $6.2 \mathrm{~km}$ per $100 \mathrm{~km}$ sq. The length of railway lines in Lower Silesia is $1763 \mathrm{~km}$ and its density is $8.8 \mathrm{~km}$ per $100 \mathrm{~km}$ sq. (second position in the country) [20]. The original length of this network was over $2900 \mathrm{~km}$ [21]. In terms of the infrastructure condition, 58\% of the railway network Lower Silesia is classified as good, $21 \%$ as satisfactory and $21 \%$ as unsatisfactory [22]. Presently, there are 24 railway sidings used by rock raw material mines and 17 railway loading points where rock raw materials are transported over a short distance from the mines using trucks. The self-government of Lower Silesia is in the process of acquiring and modernizing approximately $400 \mathrm{~km}$ of abandoned national railway lines, predominately with the intention of passenger transport [21]. The railway network, location of rock raw material loading infrastructure, and mines with active permits are presented in Figure 2.

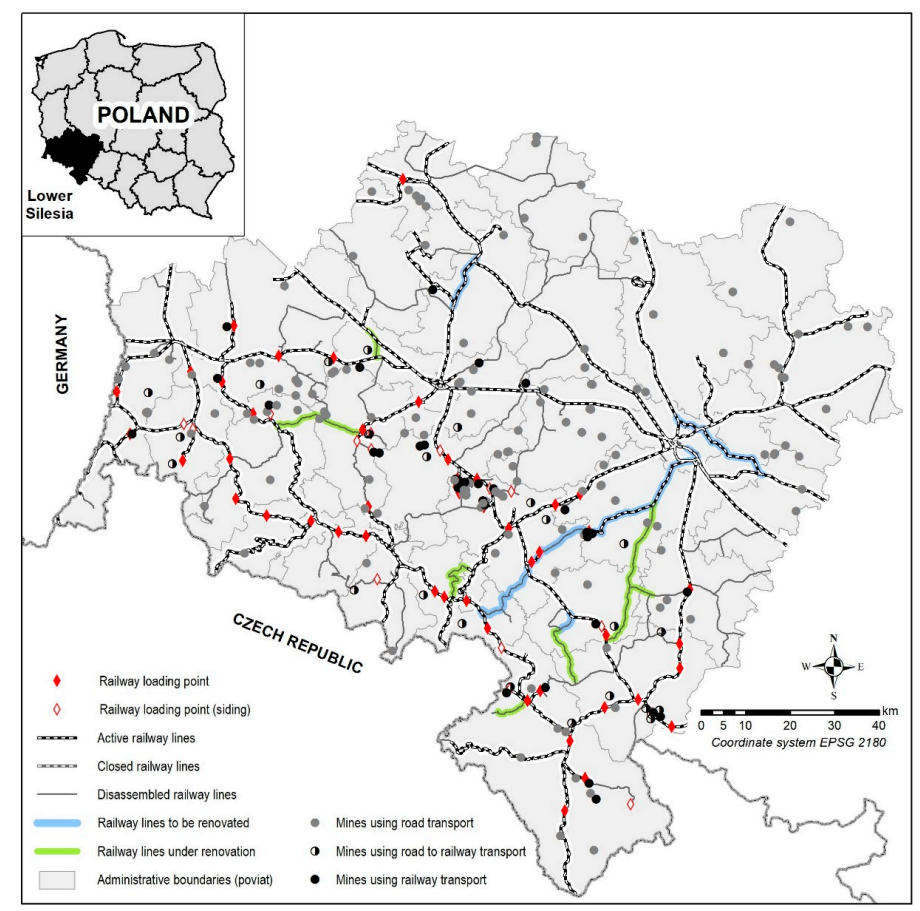

Figure 2. Scheme of the railway network in Lower Silesia with the locations of loading points and rock raw material mines. 
The average distance of commodity freight in Poland is $238 \mathrm{~km}$ [23]. The total volume of commodities transported in 2018 amounted to 250,000,000 Mg, and 52,000,000 Mg (approx. 20.8\%) of which constituted rock raw materials. The freight of rock raw materials increased by $8,000,000 \mathrm{Mg}$ compared to 2017 due to greater demand and new investments in infrastructure [24].

\section{Materials and Methods}

The primary aim of this research is to analyze and assess the volume or road transport of rock raw materials within and from Lower Silesia and the potential of railway to transport these commodities. In general, the proposed methodology involved four steps: (1) data collection, (2) data validation and statistical analysis, (3) multicriteria analysis and (4) mapping and interpretation of results. The scheme of the research methodology and techniques used in the study are shown in Figure 3.

\begin{tabular}{|c|c|}
\hline \multicolumn{2}{|c|}{ 1. Data collection } \\
\hline 1a. Desk research & $\begin{array}{l}\text { 1b. Questionnaires (telephone, email surveys, } \\
\text { personal interviews) }\end{array}$ \\
\hline Railroad administrator, & Regional mining authority, \\
\hline Regional authority, & Mining companies, \\
\hline Polish Geological Institute Databases & Local administration \\
\hline \multicolumn{2}{|c|}{$\downarrow$} \\
\hline \multicolumn{2}{|c|}{ 2. Data processing, mapping and analysis } \\
\hline 2a. Descriptive statistics and analysis & 2b. Spatial analysis \\
\hline Tabular and graphical summaries & $\begin{array}{l}\text { Mapping location of mines and railway loading } \\
\text { points, transport routes, production }\end{array}$ \\
\hline \multicolumn{2}{|c|}{$\downarrow$} \\
\hline \multicolumn{2}{|c|}{ 3. Multicriteria weighted scoring model } \\
\hline 3a. Equal weights model & 3b. Uneven weight model \\
\hline \multicolumn{2}{|c|}{ 3c. Ranking } \\
\hline \multicolumn{2}{|c|}{$\downarrow$} \\
\hline \multicolumn{2}{|c|}{ 4. Interpretation of results } \\
\hline
\end{tabular}

Figure 3. General scheme of the methodology.

Input data on the production of rock raw materials was acquired from the Polish Geological Institute database published annually in the Polish Minerals Yearbooks [18]. Data on rock raw materials transport from mines was collected through questionnaires and interviews (personal, email and telephone). Information on roads that are heavily used for truck haulage of rock raw materials was acquired through query of local authorities responsible for road infrastructure and mining companies. All 30 administrative units (poviats) and all the operating rock raw material mines were examined. The information on railway network and rock raw material sidings and loading points (in operation and potential) was obtained from regional authority (Marshal Office and Institute for Territorial Development), as well as the national Office of Rail Transport.

The following analytical techniques were used to prepare, process and analyze the data: desk research, descriptive statistics, geospatial mapping and spatial analysis in a geographical information system (GIS), as well as multicriteria scoring and ranking techniques.

Statistics describing production and transport of rock raw materials were presented in the form of graphs and tabular summaries. The following statistics, maximum, minimum, mean and median values, as well as upper and lower quartile values were calculated and used to derive a scoring system for the criteria determining the potential of rock raw material mines to introduce railway system of transport.

The assessment of mines using road transport of rock raw materials only that could potentially include or switch to rail transport was based on a scoring procedure that included the following four 
criteria: (1) distance to railway loading point, (2) annual production of rock raw materials, (3) size of available economic reserves (prognosed lifetime of a mine), (4) type of rock raw material mined. Each criterion was assessed on a three points scale where one is the lowest score and three is the highest score. In addition, value of zero was used to indicate mines that do not meet a given criterion. To be considered in the final ranking a mine had to obtain at least one point in each criterion. The following formula was applied to calculate the score (1):

$$
S_{i}=\sum_{k=1}^{n} w_{k} C_{k}
$$

where,

$S$ - total score for mine " $i$ ",

C—criterion " $k$ ",

$w$-weight of criterion " $k$ "

$n$-number of criteria.

Classification for criteria 1 and 2 was based on the results of statistics calculated for mines using railway or a combination of road and railway transport. Classification for criterion 3 was based on the amount of available economic reserves.

Two scenarios were analysed, in the first one each criterion had equal weight, whereas in the second scenario the weights were differentiated. Based on the final weighted score, a ranking of mines using road transport only was developed and presented as a list.

During the study, geospatial database and GIS analytical functions were used to determine the distance from mines to railway loading points in two ways, as a straight-line distance and along an existing road network. GIS was also used to map statistics such as length of roads presently laden with truck haulage of rock raw materials, total annual production of rock raw materials in all mines, and annual production of rock raw materials in mines using road transport only. These statistics were calculated and presented for middle (poviat) level administration units, where each one was assigned statistical values stated above and represented on thematic maps (proportional symbol maps).

\section{Results and Discussion}

\subsection{Analysis of Rock Raw Material Transport}

There have been 213 active rock raw materials mines in year 2018 in Lower Silesia. Among them, 85 are exploit deposits of dimension stones or crushed rocks, 105 are sand and gravel pits, and 23 are other mined rock raw materials (gypsum and anhydrite - 2, ceramic and refractory clay minerals- 7 , limestones and marls for cement industry -3 , feldspar -2 , kaolin -1 , dolomite -1 , magnesite -1 , mica schist-1).

The maximum reported production from a single mineral deposit was 2,676,000 $\mathrm{Mg}$ and the minimum $1000 \mathrm{Mg}$, with a mean value of $256,595.6 \mathrm{Mg}$ and a median value of $69,880 \mathrm{Mg}$. However, the largest quarry produced 3,700,000 Mg of crushed rocks $(2,676,000 \mathrm{Mg}$ migmatite and 1,024,000 Mg amphibolite).

Based on the results of desk research and inquiries, in the region, there are 37 mines using rail transport of rock raw materials, and 26 mines using a combined form of transport, i.e. road transport to the railway loading point and rail from there (among these one mine uses the combined system occasionally and has not be included in further statistics for this type of transport). The remaining 150 quarries and sand and gravel pits use road transport only. General statistics describing production and transport of rock raw materials are shown in Tables 1 and 2, as well as graphically in Figures 4 and 5. The statistics in Table 1 are aggregated by the type of transport used. The statistics in Table 2 are given by the group of rock raw materials and transport type. The graph in Figure 4 presents production values for mines using railway transport and those using road transport to nearby railway loading point in descending order, whereas the graph in Figure 5 shows the same statistic for mines using road transport only. 
Table 1. Descriptive statistics for the production of rock raw materials in mines using different means of transport.

\begin{tabular}{cccc}
\hline & Road & Road + Rail & Road \\
\hline Max. production & $2,676,000$ & $1,958,000$ & $1,053,000$ \\
Min. production & 20,000 & 40,000 & 1000 \\
Mean production & 639,731 & 620,230 & 110,035 \\
Q1 (75\%, 25\%) & 117,250 & 280,250 & 12,000 \\
Q2 (Median) & 518,500 & 462,500 & 35,000 \\
Q3 (25\%, 75\%) & 930,250 & 926,500 & 132,750 \\
\hline
\end{tabular}

Production given in Mg.

Table 2. Descriptive statistics for the production divided into the analysed rock raw material groups.

\begin{tabular}{ccccc}
\hline & & Road & Road + Rail & Road \\
\hline \multirow{4}{*}{$\begin{array}{c}\text { Dimension stones and } \\
\text { crushed rocks }\end{array}$} & Max. production & $2,676,000$ & $1,958,000$ & 330,000 \\
& Min. production & 20,000 & 40,000 & 1000 \\
& Qean production & 734,154 & 689,700 & 63,132 \\
& Q2 (Median) & 211,000 & 329,750 & 7000 \\
& Q3 (25\%, 75\%) & 587,000 & 674,000 & 23,000 \\
Sands and gravels & $1,139,750$ & $1,024,250$ & 64,750 \\
& Max. production & 788,000 & 929,000 & $1,053,000$ \\
& Min. production & 60,000 & 101,000 & 1000 \\
& Mean production & 372,200 & 388,667 & 117,894 \\
& Q1 (75\%, 25\%) & 106,000 & 258,250 & 15,000 \\
& Q2 (Median) & 184,000 & 324,500 & 34,000 \\
& Q3 (25\%, 75\%) & 723,000 & 393,750 & 135,750 \\
\hline \multirow{5}{*}{ Other rock raw materials } & Max. production & 871,000 & - & 496,000 \\
& Min. production & 28,920 & - & 1000 \\
& Q1 (75\%, 25\%) & 416,266 & - & 116,858 \\
& Q2 (Median) & 32,560 & - & 39,075 \\
& Q3 (25\%, 75\%) & 829,350 & - & 89,000 \\
& Production & - & 197,455 \\
\hline
\end{tabular}

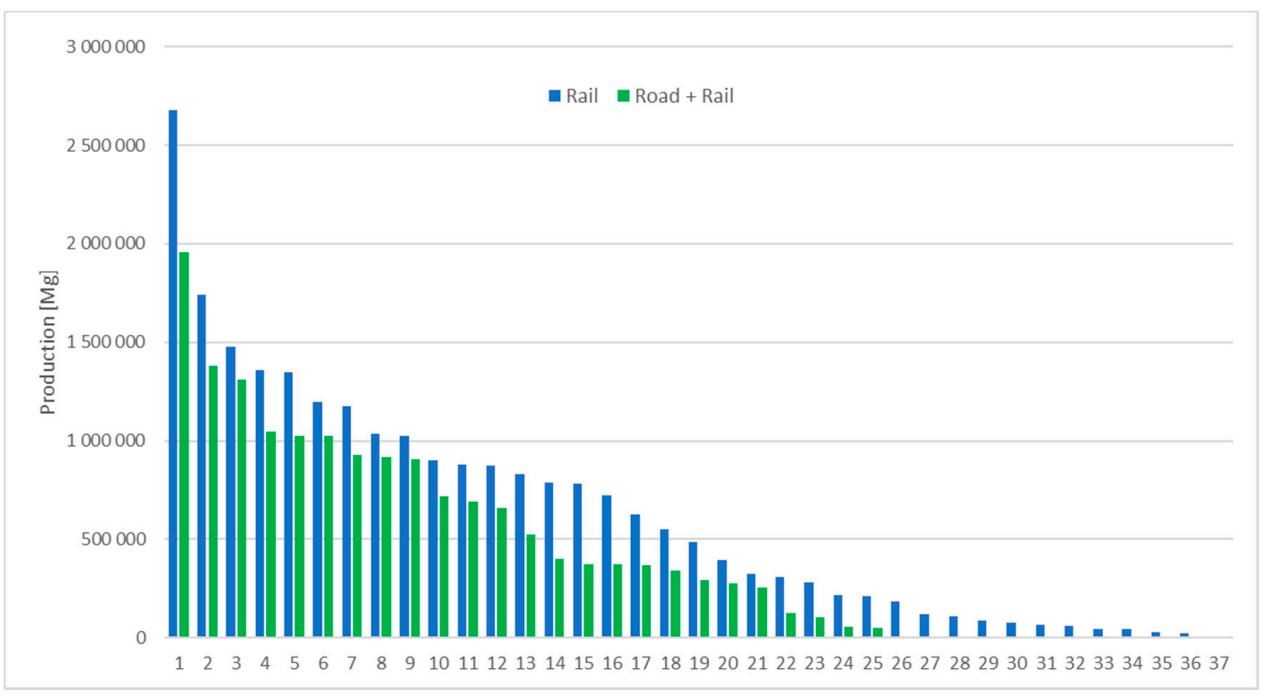

Figure 4. Production of rock raw materials in mines using road and rail transport system. 


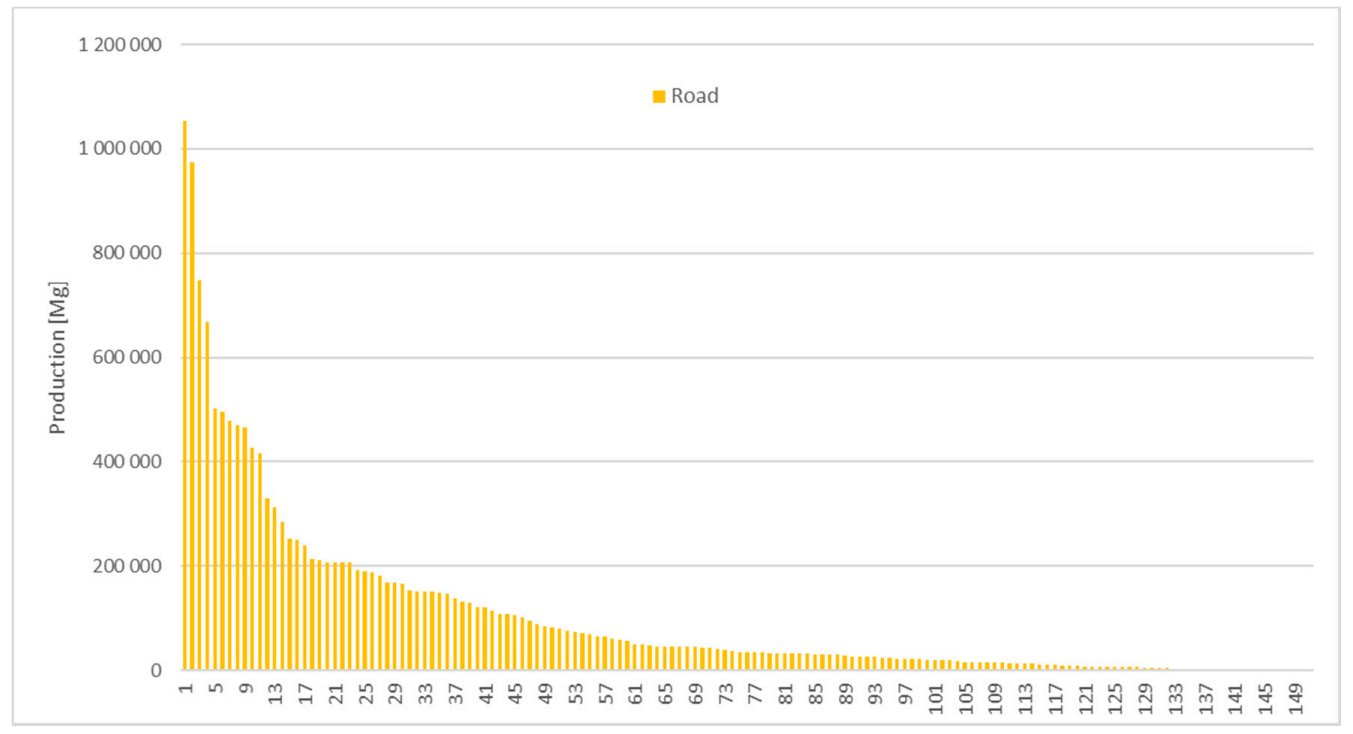

Figure 5. Production of rock raw materials in mines using road transport only.

Figure 6 presents calculated distances to nearby railway loading points in a straight line, and along the actual route for 25 mines that combine road and rail transport. The latter is on average $30 \%$ longer. The descriptive statistics for the analysed 25 cases, calculated from information collected from mines and local geological and mining authorities, are presented in Table 3. The statistics calculated for actual road network used a range of $2.1 \mathrm{~km}$ to $30.2 \mathrm{~km}$, with a mean value of $8.68 \mathrm{~km}$ and a median value of $8.0 \mathrm{~km}$. Five sites transport rock raw materials for more than $10 \mathrm{~km}$ to railway loading point, as shown in Figure 6 and 11 for more than $8.0 \mathrm{~km}$ (median value).

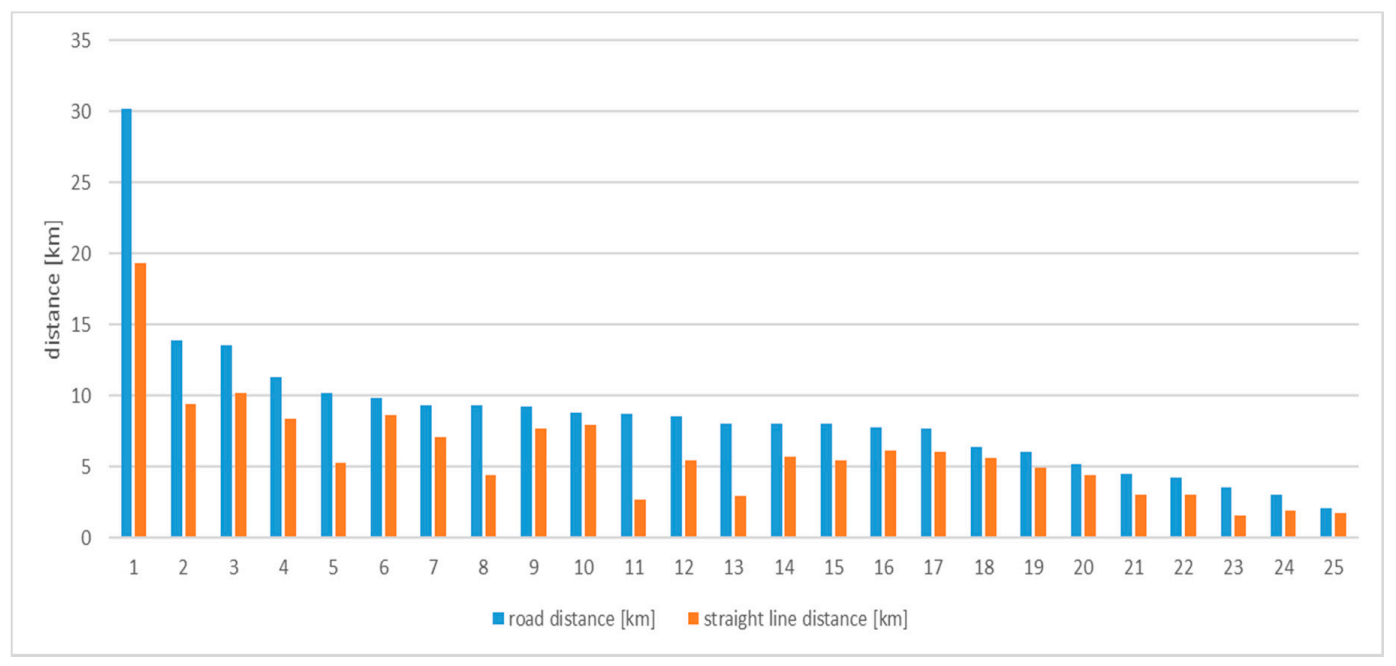

Figure 6. Distance from mine to railway loading point $(\mathrm{km})$.

Table 3. Distance statistics for combined road and railway transport.

\begin{tabular}{ccc}
\hline & Road Distance $[\mathbf{k m}]$ & Straight Line Distance $[\mathbf{k m}]$ \\
\hline Max. production & 30.2 & 19.3 \\
Min. production & 2.1 & 1.6 \\
Mean production & 8.68 & 5.94 \\
Q1 $(75 \%, 25 \%)$ & 8.0 & 5.4 \\
Q2 $($ Median) & 6.0 & 3.0 \\
Q3 $(25 \%, 75 \%)$ & 9.3 & 7.7 \\
\hline
\end{tabular}


Figure 7 presents graphically, on four proportional symbol maps, the total amount of all rock raw materials produced in each poviat of the region shown in Map A, the amount of rock raw materials produced in mines using road transport only shown in Map B, the approximate length of roads heavily used for the transport of rock raw materials in Lower Silesia's poviats shown in Map C and the actual location and size of rock raw materials in mines using road transport only shown in Map D.
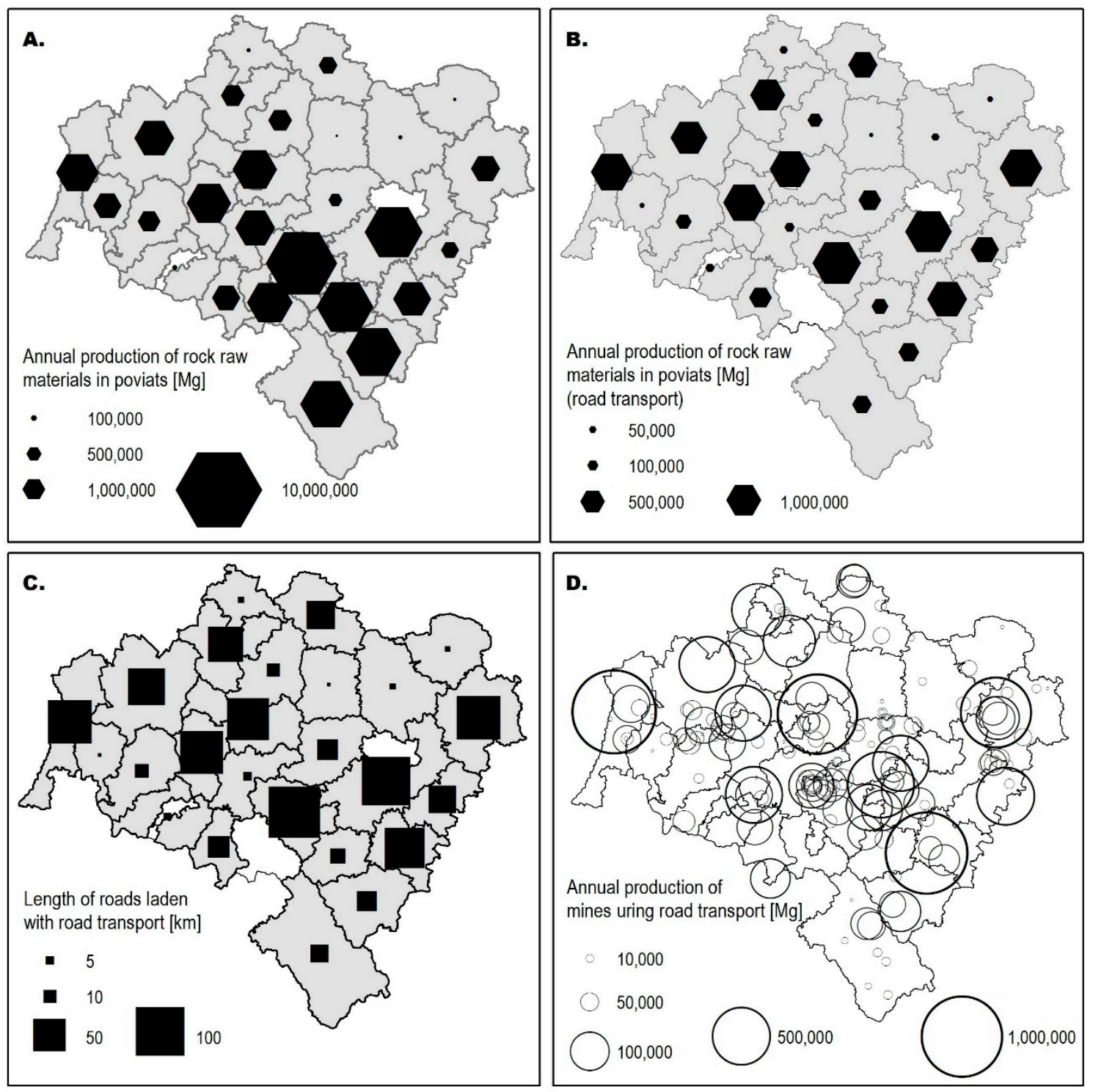

Figure 7. A. Total production of rock raw materials from mines aggregated into poviat administrative units [Mg]; B. Total production of rock raw materials from mines using road transport aggregated into poviat administrative units $[\mathrm{Mg}] ; \mathrm{C}$. Total length of roads indicated to be laden with transport of rock raw materials $[\mathrm{km}]$; D. Location and annual production of mines using road transport only $[\mathrm{Mg}]$.

Comparing Maps B and C, there is a visual relationship between poviats with the greatest production of rock raw materials in mines using road transport only and the total length of roads indicated as overloaded with the transport of theses commodities. In addition, Maps C and D show that the production and road transport of rock raw materials are concentrated in some parts of the region (in single large mining operations or clusters of medium sized mines). These results provide graphical and statistical information on the intensity of rock raw materials quarrying and transport in 
Lower Silesia, as well as background information for the multicriteria analysis of railway potential to take over share of rock raw material transport.

\subsection{Analysis of Conditions Suitable for Rail Transport of Rock Raw Materials}

The statistics obtained in part 4.1 were used for the classification of criteria and determination of scores assigned to each of the analysed mine operations. The classes and the associated scores for criteria are shown in Table 4.

Table 4. Classifications used to assign scores in each criterion.

\begin{tabular}{ccccc}
\hline $\begin{array}{c}\text { Criterion } 1 \\
{[\mathbf{k m}]}\end{array}$ & $\begin{array}{c}\text { Criterion 2 } \\
{[\mathbf{M g}]}\end{array}$ & $\begin{array}{c}\text { Criterion 3 } \\
{[\mathbf{M g}]}\end{array}$ & $\begin{array}{c}\text { Criterion 4 } \\
{[-]}\end{array}$ & Score \\
\hline$<6.0$ & $>900,000$ & $>5,000,000$ & $\begin{array}{c}\text { Rock raw materials key for national economy } \\
\text { (crushed rocks and other) }\end{array}$ & 3 \\
$6.0-8.0$ & $450,001-900,000$ & $2,000,001-5,000,000$ & Other crushed rocks & 2 \\
$8.1-9.5$ & $100,000-450,000$ & $5,000,001-2,000,000$ & Sands and gravels & 1 \\
$>9.5$ & $<100,000$ & $<500,000$ & Dimension stones, other & 0 \\
\hline
\end{tabular}

For criterion 1-distance from existing or potential railway loading point-the class intervals and the associated points were determined from descriptive statistics obtained in the previous stage. The maximum points (3) were assigned to mining sites with railway loading point at a distance of less than $6.0 \mathrm{~km}, 0$ points were given to mines located more than $9.5 \mathrm{~km}$ from a loading point.

For criterion 2-annual production-the class intervals and the associated points were also determined from descriptive statistics calculated in the previous stage. The maximum points (3) were assigned to mines with an annual output of more than $900,000 \mathrm{Mg}$ and 0 points to mines with annual output of less than 100,000 Mg. These correspond roughly to the third (upper) quartile (Q3) and first (lower) quartile (Q1), respectively, for active mines using rail or combined road and rail means of transport, as shown in Table 1. This also reflects the capacity of trains used for transport of rock raw materials. This issue is further elaborated in the latter part.

For criterion 3-economic reserves in place-the class intervals and the associated points were determined from descriptive statistics. The following values were obtained for quarrying operations using road transport only: mean $5,451,574 \mathrm{Mg}$, max. $64,343,000 \mathrm{Mg}$, min. $82,000 \mathrm{Mg}$, median (Q2) 2,077,000 Mg, Q1 642,000 Mg and Q3 5,016,000 Mg. Thus, maximum points (3) were assigned to mines with economic reserves of more than $5,000,000 \mathrm{Mg}$ and 0 points to mines with economic reserves of less than $100,000 \mathrm{Mg}$.

For criterion 4-type of rock raw material mined-the maximum points were assigned to rock raw mineral deposits of national or regional importance, 2 points to other crushed rocks deposits, 1 point to sand or gravel deposits and 0 to other mineral deposits.

Two scenarios were analysed. In the first one (scenario A), all four criteria had equal weights (0.25), in the second scenario (B), criterion 1 had the greatest weight of 0.4 , criterion 2 had the weight of 0.3 , criterion 3 had the weight of 0.2 and criterion 4 had the weight of 0.1 . Weights of criteria were adopted based on the review of literature presented in the introductory part of this paper $[2-5,7,8,12,13,25]$ and discussion regarding quarry operations. The first two criteria were discussed the most frequently and indicated as the most significant. Therefore, distance to available infrastructure and annual output were weighted higher than the other two criteria, i.e., economic reserves and type of rock.

\subsection{Analysis of the Potential for Railway Transport of Rock Raw Materials}

Out of the 150 considered mines using road transport only, 24 scored at least one point in each criterion and were included in the final ranking presenting potential of introducing railway transport. The greatest number of deposits was rejected due to low annual production (104), and the smallest number because of the type of rock (18). The results sorted from the highest to the lowest final weighted score for mines named alphabetically ' $a$ ' to ' $y$ ' is presented in Table 5. Among these, 18 represent sand 
and gravel operations, four-dimension stones and crushed rocks and two other rock raw materials. The maximum theoretical score in both scenarios was three. The calculated maximum score in Scenario A was 2.5 (mines ' $\mathrm{o}$ ', ' $\mathrm{y}$ ' and ' $\mathrm{h}$ '), the calculated minimum score 1.5 (mines ' $\mathrm{i}$ ' and ' $\mathrm{m}$ '). The median score was 2.0, whereas values of the upper and lower quartiles were 2.25 and 1.75, respectively. The maximum calculated score in scenario B was higher than that in scenario A at 2.8 (mines ' $\mathrm{o}$ ' and ' $\mathrm{y}$ ') and the calculated minimum value was 1.6 (mines ' $\mathrm{i}$ ' and ' $\mathrm{m}$ '). The median score for Scenario $\mathrm{B}$ was 2.2, whereas values of the upper and lower quartiles were 2.3 and 2.0, respectively.

Table 5. Results of multicriteria analysis of railroad transport potential for rock raw materials.

\begin{tabular}{|c|c|c|c|c|c|c|c|}
\hline No & Mine & Score C1 & Score C2 & Score C3 & Score C4 & $\begin{array}{l}\text { Final Score } \\
\text { Scenario A }\end{array}$ & $\begin{array}{c}\text { Final Score } \\
\text { Scenario B }\end{array}$ \\
\hline 1. & o & 3 & 3 & 3 & 1 & 2.5 & 2.8 \\
\hline 2. & $\mathbf{y}$ & 3 & 3 & 3 & 1 & 2.5 & 2.8 \\
\hline 3. & $x$ & 3 & 2 & 3 & 1 & 2.25 & 2.5 \\
\hline 4. & h & 3 & 1 & 3 & 3 & 2.5 & 2.4 \\
\hline 5. & c & 3 & 1 & 3 & 2 & 2.25 & 2.3 \\
\hline 6. & d & 3 & 1 & 3 & 2 & 2.25 & 2.3 \\
\hline 7. & f & 3 & 1 & 3 & 2 & 2.25 & 2.3 \\
\hline 8. & g & 3 & 1 & 3 & 2 & 2.25 & 2.3 \\
\hline 9. & q & 3 & 2 & 2 & 1 & 2 & 2.3 \\
\hline 10. & $\mathrm{t}$ & 3 & 2 & 2 & 1 & 2 & 2.3 \\
\hline 11. & $\mathbf{u}$ & 3 & 2 & 2 & 1 & 2 & 2.3 \\
\hline 12. & e & 3 & 1 & 2 & 3 & 2.25 & 2.2 \\
\hline 13. & b & 3 & 1 & 3 & 1 & 2 & 2.2 \\
\hline 14. & $\mathrm{p}$ & 3 & 1 & 3 & 1 & 2 & 2.2 \\
\hline 15. & k & 3 & 1 & 2 & 2 & 2 & 2.1 \\
\hline 16. & $\mathrm{n}$ & 2 & 2 & 3 & 1 & 2 & 2.1 \\
\hline 17. & 1 & 3 & 1 & 2 & 1 & 1.75 & 2 \\
\hline 18. & $\mathbf{r}$ & 3 & 1 & 2 & 1 & 1.75 & 2 \\
\hline 19. & $\mathbf{s}$ & 3 & 1 & 2 & 1 & 1.75 & 2 \\
\hline 20. & $\mathbf{v}$ & 3 & 1 & 2 & 1 & 1.75 & 2 \\
\hline 21. & a & 2 & 1 & 3 & 1 & 1.75 & 1.8 \\
\hline 22. & $\mathbf{j}$ & 1 & 1 & 3 & 3 & 2 & 1.6 \\
\hline 23. & i & 2 & 1 & 2 & 1 & 1.5 & 1.6 \\
\hline 24. & $\mathbf{m}$ & 2 & 1 & 2 & 1 & 1.5 & 1.6 \\
\hline
\end{tabular}

Four mines were ranked differently in Scenarios A and B. In the scenario B, with greater influence of the distance to the potential railway loading point and greater influence of annual production, mine ' $x$ ' was ranked one position higher, whereas mines ' $h$ ', ' $e$ ' and ' $j$ ' were ranked lower. Mine ' $x$ ' moved up in the ranking because of the smaller weight of criterion 4 (type of rock raw material), whereas mines ' $h$ ' and ' $\mathrm{e}$ ' dropped in the final ranking due to low scores and higher weight of criterion 2 (annual production). Mine ' $j$ ' fell in the final ranking because of low scores in the first two criteria (C1 and C2). Otherwise the results for both analyses were consistent.

Taking into account the greater importance of distance to potential loading point and annual output, as well as the statistics (median and upper quartile values) of the multicriteria ranking (Scenario $\mathrm{B}$ ), the feasibility of the top 11 mines (five (' $\mathrm{h}$ ', ' $\mathrm{c}$ ', ' $\mathrm{d}$ ', ' $\mathrm{f}$ ' and ' $\mathrm{g}$ ') of which on the condition of increased predicted production) introducing railway as a solution for rock raw material transport could be analyzed. The three mines with the highest weighted scores are large sand and gravel operations with annual output between $750,000 \mathrm{Mg}$ and 1,000,000 Mg. In this group there are also sand and gravel pits with annual productions of up to $600,000 \mathrm{Mg}$ and dimension stone and crushed rocks mines with productions between $150,000 \mathrm{Mg}$ and $350,000 \mathrm{Mg}$. The distance to potential loading points in all these cases is less than $6 \mathrm{~km}$.

The standard capacity of a train carrying rock raw material is $2400 \mathrm{Mg}$, calculated as the product of the standard number of wagon tipplers (40) and their capacity (60 Mg) or $1600 \mathrm{Mg}$ if smaller wagon tipplers are used $(40 \mathrm{Mg})$. The capacity of road trucks, i.e., gross vehicle mass (GVM), varies between 
$3.5 \mathrm{Mg}(3500 \mathrm{~kg})$ for small trucks to $16-20 \mathrm{Mg}(16,000-20,000 \mathrm{~kg})$ for larger self-unloading hopper trucks with three axles as shown in photo 1 and even $25-30 \mathrm{Mg}$ for the largest four axle trucks. The small vehicles are used for short distances and local purposes (small volumes), while the larger trucks are used for distances that exceed even hundreds of kilometers. The use of the larger and largest trucks may often be prohibited due to regulations on permissible load capacity for public roads. The advantages of road transport include flexibility, i.e., the ability to deliver rock raw materials directly to a construction site, and lower costs for shorter distance. Railway transport greatly increases the amount of rock raw materials that can be transported, and its costs become competitive to road transport as the distance increases. This is connected with additional costs such as train parking fees. In addition, unless a mine has its own siding, the rock raw material has to be delivered to the railway loading point by road transport. Gawlik et al. have estimated that for road vehicles with $16 \mathrm{Mg}$ capacity, up to $109 \mathrm{~km}$ cost of road transport is lower than that of railway transport, and that cost advantage of railway increases with this distance [2]. Kryzia and Kopacz assessed this distance to vary between $113 \mathrm{~km}$ and $324 \mathrm{~km}$ depending on the assumed cost criteria [3]. Early studies, e.g. by French [25], determined for the case study of Indiana (USA), road transport as cheaper up to the distance of 35 miles (approx. $56 \mathrm{~km}$ ), railroad transport competitive for distances of up to 230 miles (approx. $370 \mathrm{~km}$ ) and inland water transport (barge), wherever available, the cheapest above this value.

All of these studies point out that comparative cost calculations are sensitive to numerous factors such as: fuel price fluctuations, toll road charges, legal regulations regarding the permissible load capacity of road vehicles, or price discounts that can be offered by railway freight operators. Thus, railway transport may be competitive even at distances shorter than $100 \mathrm{~km}$, especially in cases of large volumes or rock raw materials than need to be delivered. We should note that it is estimated that construction, e.g., of $1 \mathrm{~km}$ of new road, requires up to 30,000 $\mathrm{Mg}$ of rock raw materials. This translates into 1200 road truck trips with a capacity of $25 \mathrm{Mg}$ [4].

In addition, the results of our investigations have indicated that even if a mine uses railway infrastructure, a portion of the production is transported with road vehicles, and road haulage will not be replaced entirely by railway. For example, the results of the query of individual mining operations in part Methodology indicate that approximately $40 \%$ of mines with railway infrastructure carry between $67 \%$ and $75 \%$ of their production by rail, $50 \%$ use equally rail and road transport and approximately $10 \%$ use rail to transport up to $35 \%$ of their production.

The presented study and its results are likely the first attempt to quantitatively assess the potential to change road transport to road and railway transport of rock raw materials based on a set of weighted criteria. The results form a foundation for further feasibility studies, where further factors could be investigated such as the condition of the connecting roads, topography, accessibility to loading points, the proportion of production to be transported beyond boundaries of the region, etc.

\section{Conclusions}

In this research, the current situation regarding the transport of rock raw materials in Lower Silesia region of Poland being the principal provider of DSCR and significant producer of sands and gravels has been investigated and statistically described based on the query of public administration, mining and transport authorities, as well as all the active mining operations.

It has been established that the majority of rock raw material mines use road transport only (150), 26 mines combine road and railway transport, and 37 use railway infrastructure on mine premises. The road transport accounts for $70 \%$ of active mine production and exerts excessive pressure on the road infrastructure condition, transport safety and environment quality.

Therefore, a method has been proposed to identify mining operations that could consider the introduction of a combined road to railway loading point and railway form of transport. The results also constitute knowledge base for local and regional authorities willing to introduce measures aimed at reducing the share of road transport of rock raw materials. 
To determine the potential of railway transport, four criteria and two scenarios were proposed and analysed. The criteria included: the distance to the railway loading point, the annual production of rock raw materials, available economic reserves (prognosed lifetime of a mine), and the type of rock raw material. Among the 24 active mines producing rock raw materials not for local (domestic) purposes, 11 have been ranked as the most matched to introduce this new form of transport.

The results demonstrate a multicriteria suitability ranking method that could be used universally for other areas of interest.

Author Contributions: Conceptualization, J.B.; methodology, J.B.; software, J.B. and A.B.; validation, J.B.; formal analysis, J.B.; investigation, J.B. and A.B.; resources, J.B. and A.B.; data curation, J.B. and A.B.; writing-original draft preparation, J.B.; writing — review and editing, J.B. and A.B.; visualization, J.B.; supervision, J.B.; project administration, J.B.; funding acquisition, J.B. All authors have read and agreed to the published version of the manuscript.

Funding: The research has been partly supported by the statutory grant at the Department of Mining and Geodesy, Faculty of Geoengineering, Mining and Geology, Wroclaw University of Science and Technology.

Acknowledgments: The research has been realized with the technical support of the Institute for Territorial Development (Lower Silesia Marshal Office) and Regional Mining Authority.

Conflicts of Interest: The authors declare no conflicts of interest.

\section{References}

1. Brown, T.J.; Idoine, N.E.; Raycraft, E.R.; Hobbs, S.F.; Shaw, R.A.; Everett, P.; Kresse, C.; Deady, E.A.; Bide, T. World Mineral Production 2013-17; British Geological Survey: Nottingham, UK, 2019.

2. Gawlik, L.; Kryzia, D.; Uberman, R. Costs of railway and road transport in the context of rock materials market balancing in Poland. Sci. Pap. Inst. Min. Eng. Wroc. Univ. Sci. Technol. 2013, 136, 21-35. (In Polish with English summary)

3. Kryzia, D.; Kopacz, M. The analysis of the conditions and transport costs of gravel and sand aggregates by rail and by heavy trucks in Poland. Logistics 2014, 4, 4573-4583. (In Polish with English Summary)

4. Nowakowski, T.; Kwaśniowski, S.; Zając, M. Logistics problems of rock yield carriage in Lower Silesia region in face of co-modality. Logistics 2013, 4, 2010. (In Polish with English summary)

5. Chęciński, S. Rock raw materials haulage routes modelling with GIS environment. Min. Sci. Miner. Aggreg. 2014, 21, 27-35. (In Polish with English summary)

6. Beuthe, M.; Jourquin, B.; Geerts, J.F.; à Ndjang'Ha, C.K. Freight transportation demand elasticities: A geographic multimodal transportation network analysis. Transp. Res. Part E 2001, 31, 253-266. [CrossRef]

7. Łochańska, D.; Stryszewski, M. Logistics considerations as for satisfying a demand for rock raw material depending on its kind, quality as well as optimisation of roads and resources. Górnictwo Odkryw. Open Cast Min. 2011, 6, 96-99. (In Polish with English summary)

8. Stryszewski, M.; Łochańska, D. Transport as a regionalisation factor of rock raw materials mining production. Górnictwo Odkryw. Open Cast Min. 2013, 5, 146-150. (In Polish with English summary)

9. Blachowski, J. Spatial analysis of the mining and transport of rock minerals (aggregates) in the context of regional development. Environ. Earth Sci. 2014, 71, 1327-1338. [CrossRef]

10. Kendall, A.; Kesler, S.E.; Keoleian, G.A. Megaquarry versus decentralized mineral production: Network analysis of cement production in the Great Lakes region, USA. J. Transp. Geogr. 2010, 18, 322-330. [CrossRef]

11. Andrés, L.; Padilla, E. Energy intensity in road freight transport of heavy goods vehicles in Spain. Energy Policy 2015, 85, 309-321. [CrossRef]

12. Robinson, G.R.; Kapo, K.E. A GIS analysis of suitability for construction aggregate recycling sites using regional transportation network and population density features. Resour. Conserv. Recycl. 2004, 42, 351-365. [CrossRef]

13. Hill, M.P. Aggregate opportunity modelling: Understanding our resource and planning for the future. In Proceedings of the AusIMM NZ Branch Conference 2018, Tauranga, New Zealand, 17-18 September 2018.

14. Central Statistical Office. Local Data Bank. Available online: www.stat.gov.pl (accessed on 16 January 2020).

15. Oberc, J. Geological Structure of Poland, 2nd ed.; Geological Publishing House: Warsaw, Poland, 1972. (In Polish)

16. Stupnicka, J. Regional Geology of Poland, 3rd ed.; Warsaw University Press: Warsaw, Poland, 2007. (In Polish) 
17. Koźma, J. Mineral resources-State and potential for development. In Ecophysiographical Study of the Lower Silesia Voivodeship, 2nd ed.; Lower Silesia Marshal Office: Wroclaw, Poland, 2005. (In Polish)

18. Polish Geological Institute. Balance of the Mineral Resources and Underground Waters of Poland. 2019. Available online: http://geoportal.pgi.gov.pl/surowce (accessed on 11 February 2020).

19. Osika, R. Geology and Mineral Resources of Poland, 2nd ed.; Geological Publishing Office: Warsaw, Poland, 1970. (In Polish)

20. Office of Rail Transport. Railways in Voivodeships-Use and Transport Policy. 2019. Available online: https://utk.gov.pl/ (accessed on 31 January 2020).

21. Zakęś, A. Railway Network in the Lower Silesia Region; Lower Silesia Marshal Office: Wrocław, Poland. Unpublished. (In Polish)

22. Office of Rail Transport. Railways in Voivodships-Dynamics of Changes. 2017. Available online: https://utk.gov.pl/pl/dokumenty-i-formularze/opracowania-urzedu-tran/15443,Kolej-wwojewodztwach-wykorzystanie-i-polityka-transportowa.html (accessed on 31 January 2020).

23. Office of Rail Transport. Statistics of Freight Transport 2000-2018. Available online: https://utk.gov.pl/pl/ aktualnosci/ (accessed on 31 January 2020).

24. Office of Rail Transport. Transport of Freight Groups in 2018. Available online: https://utk.gov.pl/pl/ dokumenty-i-formularze/opracowania-urzedu-tran (accessed on 31 January 2020).

25. French, R.R. Transportation of Mineral Aggregates in Indiana. Proc. Indiana Acad. Sci. 1968, 7, 348-354.

(C) 2020 by the authors. Licensee MDPI, Basel, Switzerland. This article is an open access article distributed under the terms and conditions of the Creative Commons Attribution (CC BY) license (http://creativecommons.org/licenses/by/4.0/). 